\title{
Strategic Default and Personal Credit: The Brazilian Natural Experiment
}

\author{
Christiano Arrigoni Coelho (BCB and PUC-Rio)* \\ Bruno Funchal(EPGE/FGV) ${ }^{\dagger}$
}

\begin{abstract}
Brazil provided at 2004 an interesting natural experiment concerning personal credit. The government implemented a new law that allows some financial institutions to offer a specific type of credit. This new law removes a significant share of the moral hazard problem, since the main feature of this type of credit is the deduction of the debt repayment directly from the debtors' payroll check, eliminating the choice of default when debtors are able to pay their loans with their wage. Taking advantage of this fact, we estimate - using the differencein-difference procedure - the cost of such type of informational failures. We find that the new law produced a decrease in the interest rate charged to personal loans, while the volume of personal credit increased, as expected, improving personal credit market conditions. Both effects are economically and statistically significant.

Keywords: Credit Market, default, moral-hazard, difference-in-difference, law.

JEL Codes: E44, D01, C33, K00.

ANPEC's Area 7: Microeconomics, Quantitative Methods and Finance.
\end{abstract}

\section{Resumo}

No ano de 2004 o Brasil proporcionou um interessante experimento natural no que diz respeito ao crédito pessoal. O governo implementou uma nova lei que permite algumas instituições financeiras a oferecer um tipo específico de crédito. Essa nova lei elimina uma parte significativa do problema de azar moral, uma vez que a principal característica desse tipo de empréstimo é a possibilidade de deduzir seu pagamento diretamente da folha de pagamento dos devedores, eliminando a escolha do default quando devedores são capazes de pagar de seus empréstimos com seus salários. Aproveitando esse fato, estimamos - usando o procedimento de diferenças-em-diferenças - o custo de tal tipo de falha informacional. Como resultado, encontramos que a nova lei proporcionou uma redução nos juros cobrados pelos empréstimos pessoais, enquanto que o volume de empréstimos aumentou, melhorando as condições do mercado de crédito pessoal. Ambos os efeitos são estatisticamente e economicamente significativos.

Palavras Chaves: Mercado de Crédito, default, azar moral, diferenças-em-diferenças, lei. Códigos JEL: E44, D01, C33, K00.

Area ANPEC 7: Microeconomia, Métodos Quantitativos e Finanças.

\footnotetext{
*e-mail:christiano.coelho@bcb.gov.br. Mr. Coelho would like to stress that opinions expressed here are solely his, and do not reflect any official position of the Brazilian Central Bank.

†e-mail: bfunchal@fgrmail.br
} 


\section{Introduction}

At the end of 2003 the Brazilian Congress approved a new law that regulates payroll loans. The payroll loan is a type of personal credit with repayments directly deducted from the borrowers' payroll check, which, in practice, makes a collateral out of future income.

Before the implementation of the new law, only workers, pensioners and retired workers from the public sector had access to this type of credit. The new law comes to provide such credit to private workers associated to trade unions, pensioners and retired workers from the National Institution of Social Security (INSS) ${ }^{1}$. Only some financial institutions (those authorized by the government) are able to provide this loan for the INSS beneficiaries.

The new law provides to creditors the capacity to receive their loans' repayment immediately, whenever the debtors have enough wage to do it. Thus, such type of loan eliminates a significant part of the strategic default, diminishing the informational failure costs, as moral hazard. The reduction of default's probability increases the expected repayment for the lenders making them willing to offer more credit at better terms.

Taking advantage of this natural experiment our objective is to identify the average effect of the new law on personal credit, more specifically over the amount of new loans and interest rates. Also, besides the final impact over personal loans, we aim at verifying both the direct and indirect effects of the new law. In this paper we call direct effect the impact of the new law over the financial institutions that were authorized by the government to offer the payroll loans, and indirect effect the impact over the financial institutions that were not allowed to offer such type of loans.

The econometric method used in this paper is the difference-in-difference procedure. Our analysis uses the fact only the personal credit ${ }^{2}$ was benefited with the new law, making them the treatment group. As control group we use automobile loans since this type of credit has similar features when compared with personal loans ${ }^{3}$, also since the interest rate charged to automobile credit is lower than the one charged to personal credit, it minimizes the potential migration effect that could happen if another type of loan with higher interest rate was used. In the empirical section we address the test of quality of such control, showing that it is a good control. The variation across time and type of credit provides a potential instrument to identify the causal effect of the new law on personal credit market.

The difference-in-difference approach owns several advantages. Our estimator has less bias than a simple mean estimator once we have a control group. For example, in the period before the new law's enforcement the mean of the basic interest rate (taxa selic) was $1.63 \%$ per month while in the period after the enforcement this mean rate was $1.36 \%$. If we estimated the new law's effect using the simple difference between the interest rate for the treatment group before and after new law's enforcement we would have a biased estimator, since part of the interest rate decrease in this period is due to the basic interest rate fall. With the difference-in-difference procedure we can have an unbiased estimator without any kind of macroeconomic control. Otherwise, if we estimated the effect using the simple mean we would have to include macroeconomic controls, which increase the number of parameters to be estimated, putting more uncertainty in our estimation and reducing the power of the test. Also, the exogenous nature of the new law is a good opportunity to study how the costs of informational failures affects the personal credit market, without endogeneity

\footnotetext{
${ }^{1}$ The Brazilian pension system, a pay-as-you-go scheme, is publicly managed by this governmental agency, INSS.

${ }^{2}$ Personal credit is composed by two modalities of credit: CDC (direct credit to consumer) and payroll loans.

${ }^{3}$ The similarity between both types of credit comes from the collateral. The personal credit, composed by CDC (direct credit to consumer) and payroll loans, owns as collateral the client banking account and the payroll check respectively, i.e, the bank can deduct the loan repayment direct from the client account and payroll check. Automobile credit, instead, owns as collateral the vehicle that was bought with such loan.
} 
problems.

In the end, we find that the new law that regulates payroll loans is actually associated with an increase of the volume of new personal loans and a reduction in its interest rates, which indicates that the costs generated by information failures is highly significant for the personal credit market. For the institutions directly effected the same results are observed, but stronger. Financial institutions that were not directly affected also suffered, in some way, an impact with the implementation of the new law. In this case, however, we notice a reduction in the volume of the new personal loans, which represents a migration of clients from financial institutions that are not able to offer payroll loans to institutions that are allowed to do that. Also, in the same direction of directly affected financial institutions, a reduction in the interest rate for personal loans was observed. The explanation for this result comes from the fact that the demand for credit decreases for such institutions due to the migration of their clients to institutions benefited with the new law.

As the measure of the indirect impact of the new law on the institutions not able to give payroll loans shows, this event meant a downward shift of personal credit's demand for such financial institutions. So, using only this sample, we are able to estimate the credit supply elasticity of personal loans. To do this we divide the proportional estimated effect on the new loans by the proportional estimated effect on the interest rate. The results point to an estimated elasticity varying from 8.7 to 10.8 . These numbers mean that a $1 \%$ variation in the interest rate causes new loans variation between $8.7 \%$ and $10.8 \%$. Thus, the estimated elasticity shows a very steep credit supply.

On this subject Costa and Mello (2005) estimated the effect of judicial decision on the legality of payroll debt loans in Brazil. In June 2004, a high-level federal court upheld a regional court ruling that had declared payroll deduction illegal. Evidence indicates that it had an adverse impact on banks' risk perception, on interest rates and on the amount lent. Coelho, Garcia and Mello (2006) studied the presence of credit rationing in the Brazilian market using two different tests. First, they tested interest rate stickiness and then they do a natural experiment using the new law in order to detect credit rationing for corporate firms. In the first test they found no evidence of interest rate stickiness. In the second one, interest rate went up and new loans volume went down after a negative supply shock. Both evidences go on opposite directions to credit rationing theory predictions.

The remainder of the paper is structured as follows: in section 2 we describe the new law and its particularities; in section 3 we describe the database used and the main descriptive statistics; section 4 presents the empirical results; and section 5 concludes.

\section{The New Law}

The specific legislation of payroll loans is not new in the Brazilian financial scenario. The Law 8,112 of December 1990 already validated such type of credit, however applying just to workers, retires and pensioners of the public sector. For the private sector there was no specific law so far, which brought serious difficulties for the development of this type of credit. Private retires and pensioners didn't have permission to do such operation and private workers should create a particular instrument between three parts: employee, employer and financial institution. The significant change in this legislation occurred in September 2003, when the government sent to the House of Representatives the $\mathrm{MP}^{4} 130$ that subsequently, in December 2003, turned into Law

\footnotetext{
${ }^{4} \mathrm{MP}$ is the abbreviation of Medida Provisória that is a legislative device in which the executive sends a bill to congress that is effective immediately, pending approval. It has an urgency status that forces the legislator to appreciate its merit. For practical purposes, it is almost equivalent to a full-blown law.
} 
10,820. The new law created juridical security of salary consignation through private companies and the National Institution of Social Security (INSS) to private sector formal workers and retired workers respectively. Such type of loans has some boundaries related to the agent income, however. Monthly deductions are limited to thirty percent of agents' disposable wage ${ }^{5}$; the loans should have fix payment during the amortization period; and rescissory earns ${ }^{6}$ can be consigned for the amortization of the remainder debt. Employers have several obligations relative to the values and information that are passed to the financial institutions and employees. To make competitive conditions to the employees, the participation of the trade union entities representing the employees is obligatory, but despite the agreement between the trade unions and some financial institution, the employee is free to choose any financial institution that supply this type of credit.

Despite the law be in force since September 2003, just in April $2004^{7}$ it really took effect when the government authorized the Caixa Econômica Federal ${ }^{8}$ to offer this type of credit to the pensioners and retired workers from INSS, supported by the new law. Subsequently, BMG (Bank of Minas Gerais) was the first private bank to assign such agreement. Today there are forty four financial institutions authorized by the government to supply this type of credit to pensioners and retired workers from INSS ${ }^{9}$.

\section{Description of the data and Descriptive Statistics}

The database comes from Central Bank of Brazil according to circular 2.957 of 12/30/1999 and comunicado 7.569 of $05 / 20 / 2000$.

The database contains daily information about new loans and interest rate. All information is displayed by financial institution, type of loan indexation (prefixed, interest rate indexation, exchange rate indexation and price indexation) and kind of borrower (household or firm).

The article uses information about personal loans and automobile loans. Personal loans are credit to households, with considerable screening by financial institutions. The bank's client must have an account with the bank and generally the bank deducts the loans payment from this account, when this has enough funds. Personal loans are composed by two modalities of credit: CDC (direct credit to consumer) and payroll loans. The difference between these two kinds of loans is that in the first one there is no guarantee that the client will not change the bank that he receives his wage while in the payroll loans the client is not allowed to change the bank that he receives his wage once he has singed a loan contract with the bank. These two kinds of loans are not linked with the purchase of a specific good, so the borrower can buy any kind of good or even repay other debts with the loans' proceeds. We use only the prefixed loans, since it is the most usual type of personal credit.

Automobile loans are credit to households that are used to buy automobiles. In this kind of credit the automobile is the collateral of the transaction. Like in the previous case we use only prefixed loans since they are the most usual in this market.

The sample consists in a group of 112 financial institutions offering personal loans and 57

\footnotetext{
${ }^{5}$ Wage after the compulsory deductions like taxes, pensions, etc.

${ }^{6}$ Rescissory earns comprise all rights of the employee for a contractual break.

${ }^{7}$ To define the exact month that a institution became able to give payroll loans we used the following criteria: when the date of the deal signature was in the first half of the month we considered the same month, otherwise we considered the next month. For example, Caixa Econômica singed the deal in 04/19/2004, so we considered May as the date that it became able.

${ }^{8}$ The Caixa Econômica Fedral is the biggest public bank.

${ }^{9}$ For more details about the date of authorization see Appendix A.
} 
offering automobile loans. From the 112 institutions of personal loans market there is a sub sample of 40 financial institutions that are able to give payroll loans according to the new law.

We run our empirical tests using monthly data generated through the daily data. The new loans variable is constructed by summing of daily values over the whole month. For the interest rates variable, we use the monthly average, weighting up by respective new loan volume. The sample period is from January 2003 to October 2005, so our sample consists of 34 months and 57 and 112 cross sections units of automobile and personal loans respectively (5,746 observations).

\section{Figure 1: Mean of new loans before and after the new law}

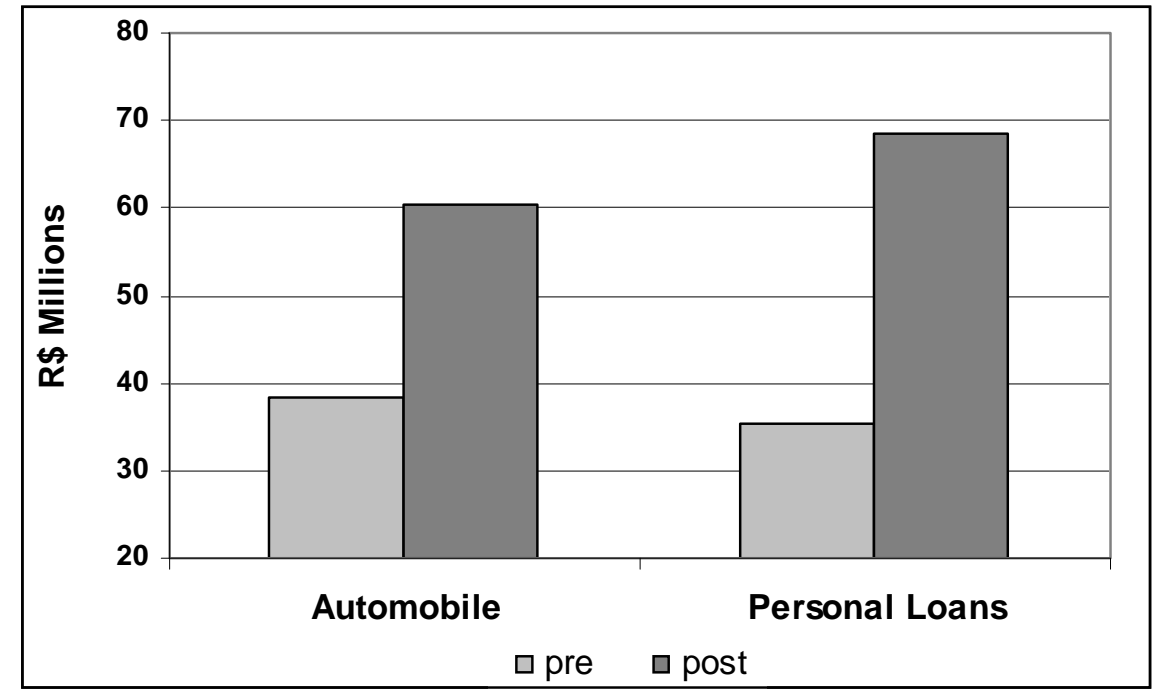

Now we present some descriptive statistics concerning personal and automobile loans before and after the new law of payroll loans take effect. Figure 1 illustrates a strong increase of the new loans volume for personal and automobile loans in the period after the new law take effect. The monthly average of personal credit new loans increased from $\mathrm{R} \$ 35.4$ millions to $\mathrm{R} \$ 68.7$ millions, i.e., a rise of $\mathrm{R} \$ 33.3$ millions which meant a growth rate of $94.2 \%$. The monthly average of automobile new loans increased from $\mathrm{R} \$ 38.5$ millions to $\mathrm{R} \$ 60.5$ millions, i.e., a rise of $\mathrm{R} \$ 22$ millions which meant a growth rate of $57 \%$.

Table 1: New Loans

\begin{tabular}{lccc}
\hline & \multicolumn{3}{c}{$\mathrm{R} \$$ Millions } \\
& pre & post & growth rate \\
\hline Personal Loans & 35,4 & 68,7 & $94.2 \%$ \\
Automobile & 38,5 & 60,5 & $57.0 \%$ \\
\hline
\end{tabular}

The monthly average interest rate (\% per month) for personal loans decreased from $5.04 \%$ per month before the new law to $4.15 \%$ after, i.e., a reduction of $0.89 \%$ per month, which annualized means a fall of $11.22 \%$ per year. For automobile loans, the monthly average interest rate decreased from $2.55 \%$ to $2.41 \%$, i.e., a reduction of $0.14 \%$ per month, which annualized means a fall of $1.69 \%$ per year. Thus, the interest rate decline was almost seven times bigger for personal loans in annual terms. Even though there were timing factors that decreased the interest rates for both personal and automobile loans, the reduction for the personal loans was much deeper. 
Figure 2: Mean of interest rate before and after the new law

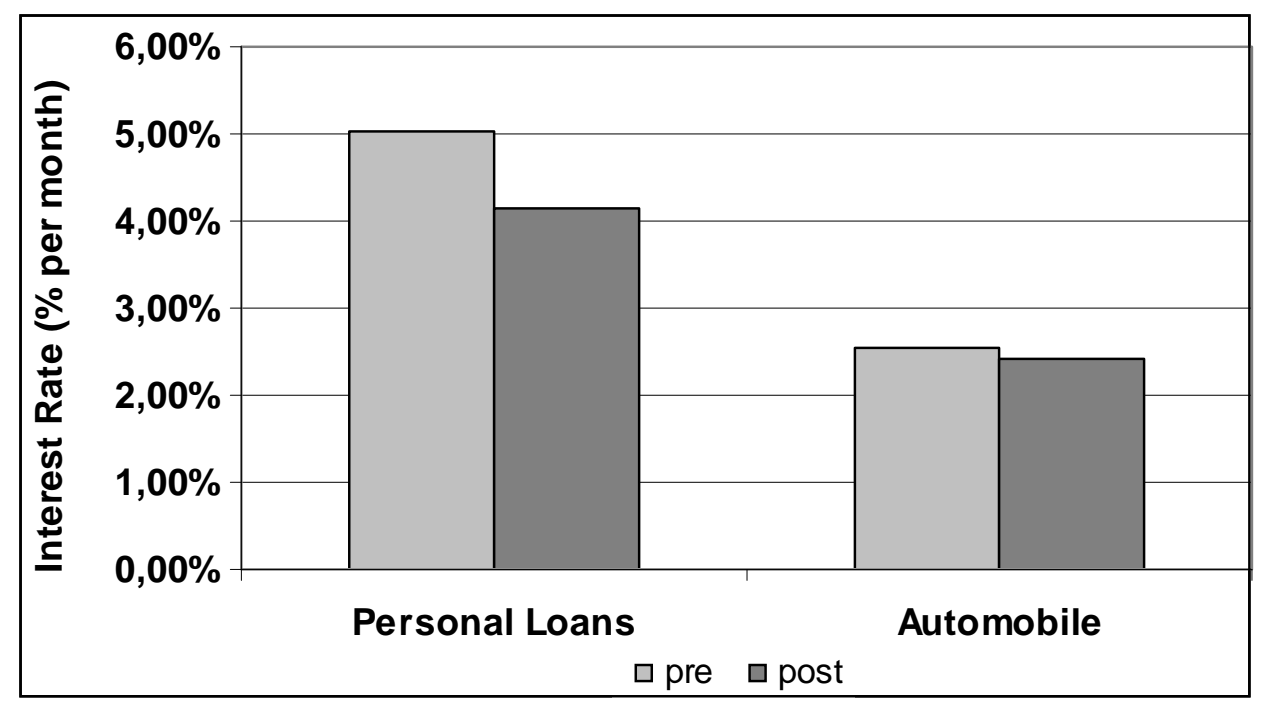

Table 2: Interest rate

\begin{tabular}{lccc}
\hline & \multicolumn{2}{c}{$\%$ per month } & \\
& pre & post & growth rate \\
\hline Personal Loans & $5,04 \%$ & $4,15 \%$ & $-17,69 \%$ \\
Automobile & $2,55 \%$ & $2,41 \%$ & $-5,59 \%$ \\
\hline
\end{tabular}

Analyzing the above information as growth rate, we notice that the new law affects strongly the personal loans in both considered variables (see Figure 3). The personal new loans suffered a much higher increase than the automobile new loans, 94\% against 57\%. Also, the reduction of the interest rate was much stronger for personal loans, $17 \%$ against $5 \%$.

To sum up, the descriptive statistics show that at the time which new law was implemented, there was a generalized downward trend in the interest rate and upward trend in the new loans volume, but these trends were more pronounced for personal loans.

Figure 3: Gowth Rates - personal loans x automobile

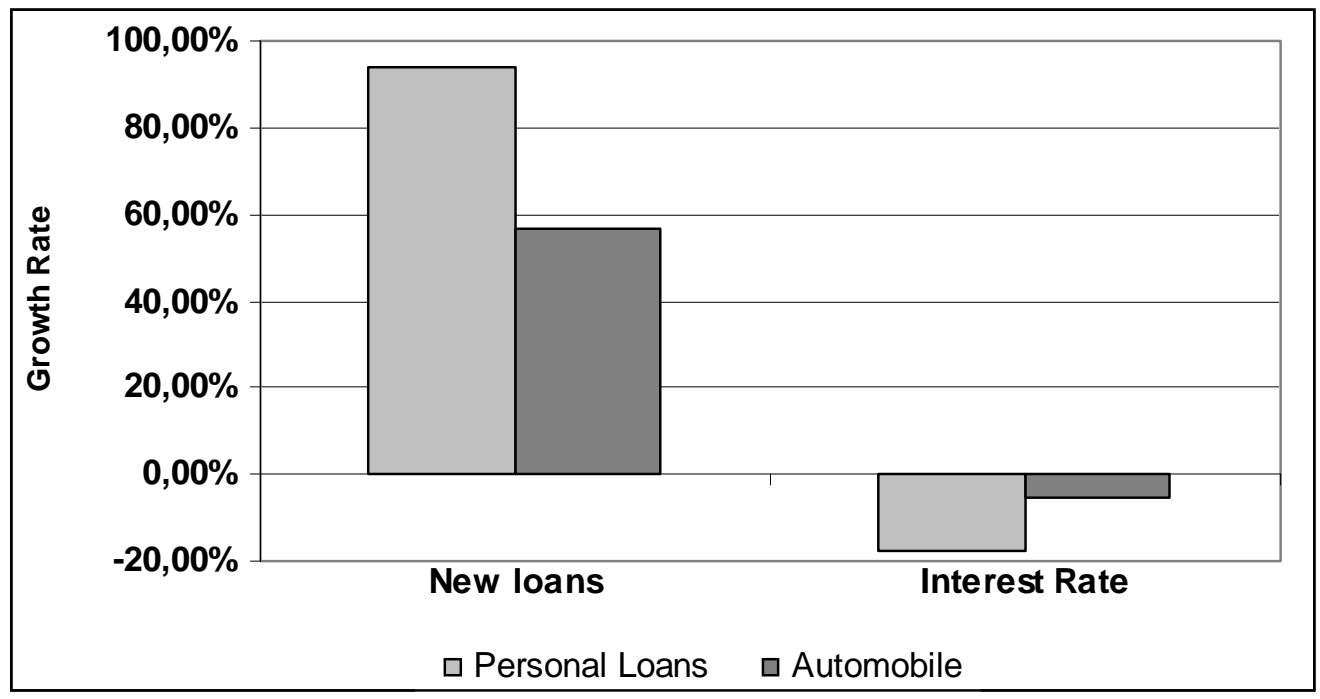




\section{Empirical Tests}

In this section our objective is to identify the average effect of the new law on personal credit, i.e., the average impact of treatment on the treated. Specifically, we are interested in comparing personal loans when payroll loans are allowed to the counterfactual, that is, personal loans when payroll loans are not allowed for the treatment group at the same point in time. Since the counterfactual is never observed, we must estimate it.

In principle, we would like to randomly assign the type of credit benefitted and non-benefitted with the new law and compare the average outcomes of the two groups. In the absence of a controlled randomized trial, we are forced to turn to nonexperimental methods that mimic it under reasonable conditions. A major concern is that the personal credit could be significantly different from the type of credit that are not affected by the new law and that these differences may be correlated with our dependent variables. In principle, many of the types of (unobservable) characteristics that may confound identification are those that vary across types of credit but are fixed over time. A common method of controlling for time-invariant unobserved heterogeneity is to use panel data and estimate difference-in-differences models.

Therefore, without the benefit of a controlled randomized trial, we turn to a difference-indifferences approach, which compares the change in outcomes in the treatment group before and after the intervention to the change in outcomes in the control group. By comparing changes, we control for observed and unobserved time-invariant characteristics to the pair type of creditfinancial institution that might be correlated with the government authorization as well as with personal loans. The change in the control group is an estimate of the true counterfactual, that is, what would have happened to the treatment group if there had been no intervention. In this paper we use automobile loans since we believe that its fulfill the characteristics of a good control. Another way to state this is that the change in outcomes in treatment group controls for fixed characteristics and the change in outcomes in the control group controls for time-varying factors that are common to both control and treatment groups.

The difference-in-difference model ${ }^{10}$ can be specified as a two-way fixed-effect linear regression model:

$$
y_{i t}=c_{i}+\varphi_{t}+\beta \cdot d I_{i} \cdot d T_{i t}+\varepsilon_{i t} .
$$

The right-hand side of the equation include fixed effects to the pair type of credit-financial institution to control for specific factors that are fixed over time, the month fixed effects to control for factors that vary over time but are common across the cross-section, and the coefficient $\beta$ that is the difference-in-difference estimator of the impact of new law of payroll loans.

We define the diff-in-diff dummy variable as $d I_{i} \cdot d T_{i t}$, where:

- $d I_{i}$ : is a dummy variable that assumes 1 when the cross section unit i belongs to the treatment group (the financial institutions that provide personal loans) and 0 otherwise;

- $d T_{i t}$ : is a dummy variable that assumes 1 if the observed period is after the regulation of the payroll loans concession according to the new law and 0 otherwise. For the institutions that are able to give payroll loans this dummy variable is 1 after the date that the institution singed the contract with the INSS, that made it able to give payroll loans for retires and pensioners and 0 otherwise. For the institutions that are not able such date is arbitrary, so we will estimate some models varying the threshold point.

\footnotetext{
${ }^{10}$ See Meyer (1995).
} 
In this model, $\beta$ is the difference-in-difference estimate of the (average) effect of new law of payroll loans on personal loans. The key identifying assumption for this interpretation is that the change in loans variables in control group is an unbiased estimate of the counterfactual. While we cannot directly test this assumption, we can test whether the secular time trends in the control and treatment variable of loans were the same in the preintervention periods. If the secular trends are the same in the preintervention periods, then it is likely that they would have been the same in the postintervention period if the treated type of loan had not suffered influence of the new law.

Figure 4: Evolution of the New loans

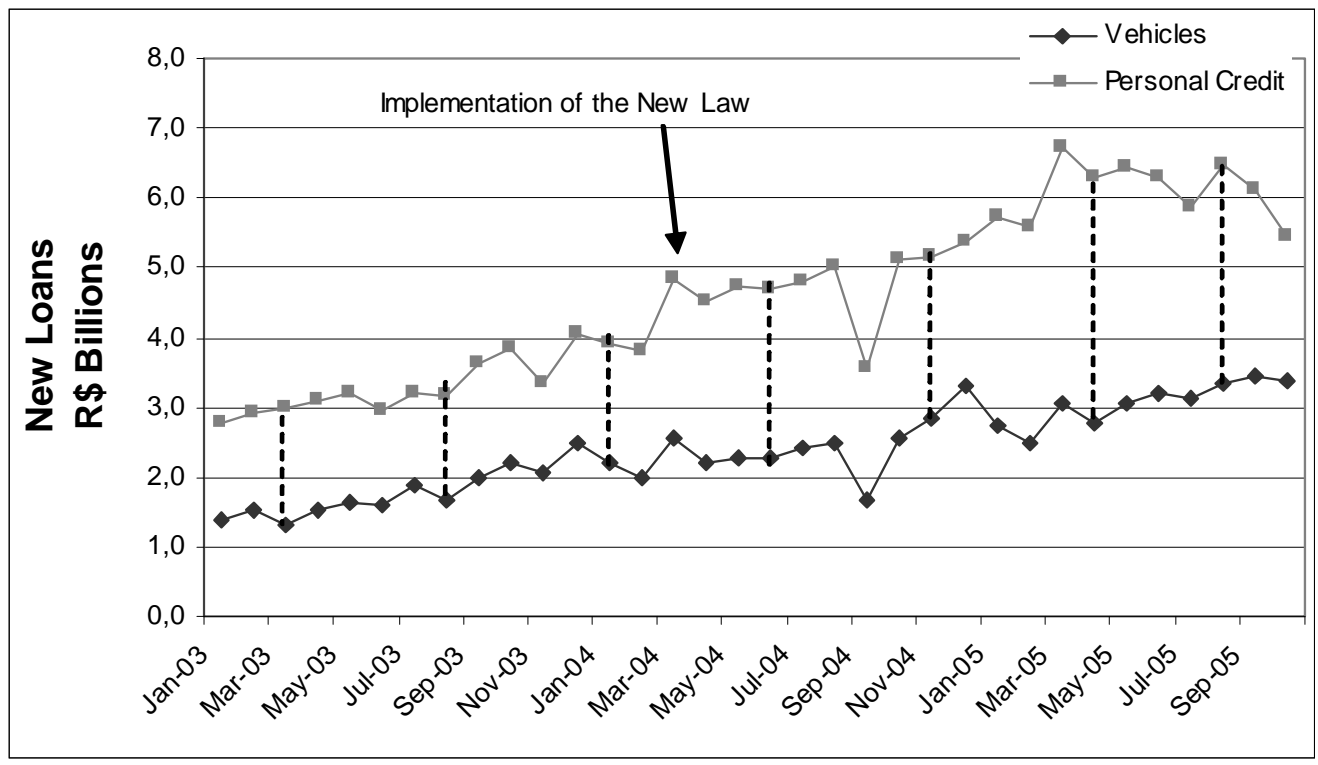

Figure 5: Evolution of the Interest Rate

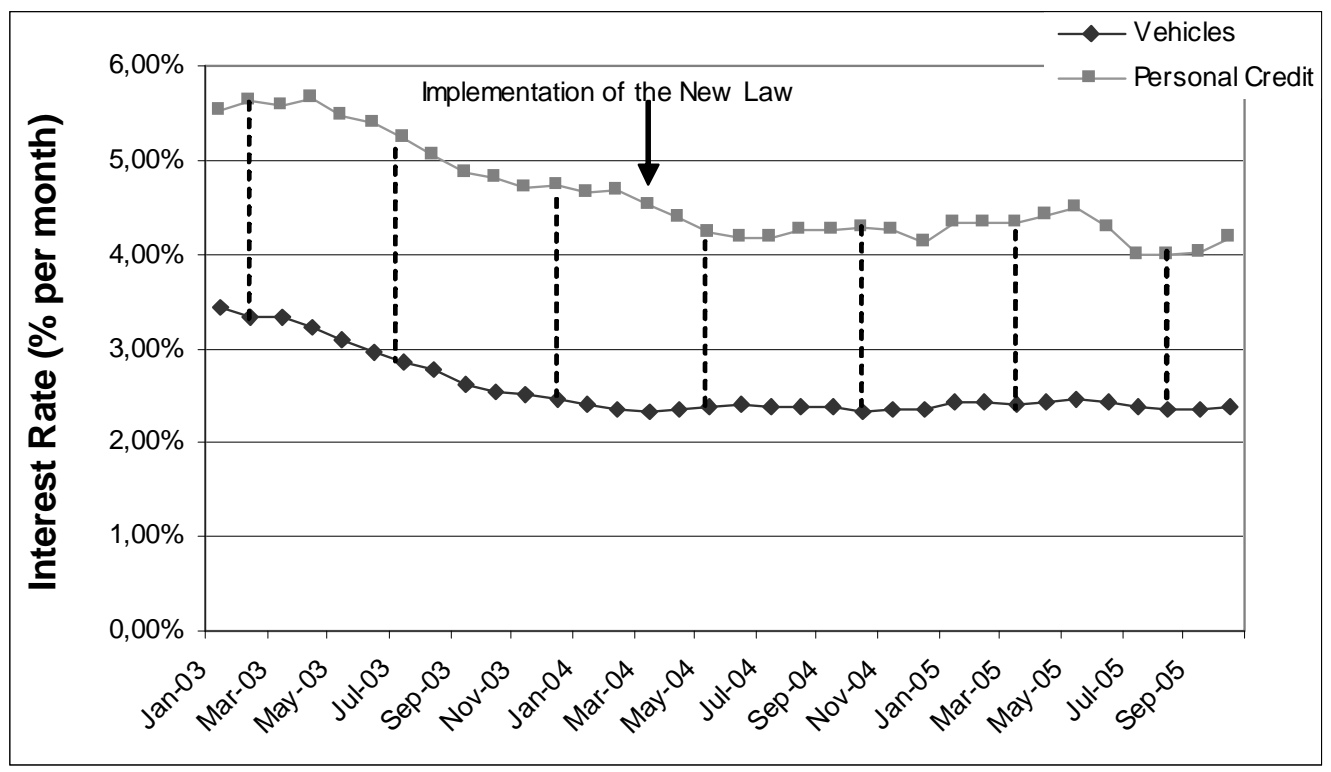

Figures 4 and 5 already suggest that the growth in interest rates and new loans in treatment (personal loans) and control (automobile loans) groups were the same before the new law take effect. Notice that for the period before the new law the path of both variables for the control group is similar to the treatment group, occurring a detach only after the new law implementation. This 
feature would indicate that the variable automobile loans could be a good control for the treatment group personal loans.

We formally test that the preintervention time trends for the control and treatment groups are not different by testing the hypothesis that growth in new loans and interest rates for both groups was the same in the pre-new law period. To conduct the test we regress changes in new loans and interest rates over the period January 2003-March 2004 against an indicator of the type of loan and dummies of month and cross-section characteristics. The hypothesis is rejected if the coefficient on the dummy of type of loans is significantly different from zero. The results are presented in column 1 and 2 of table 3 . We cannot reject the hypothesis that growth in both variables was the same in both control and treatment groups in the pre-new law period.

Tabela 3: Growth Rate (Difference)*

\begin{tabular}{lcc} 
& New Loans & Interest Rate \\
& OLS & OLS \\
& $(1)$ & $(2)$ \\
Personal Loans $(=1)$ & 0.66 & -0.07 \\
& $(0.49)$ & $(0.44)$ \\
\hline Fixed effects & Yes & Yes \\
Number of obs & 1585 & 1557 \\
No de cross sections & 127 & 127 \\
R-squared & 0,17 & 0,07 \\
\hline${ }^{*}$ p-value in parentheses & & \\
Robust standard errors & &
\end{tabular}

\subsection{Direct Effects}

In this subsection we analize the direct effect of the new law. This effect is defined as the impact of the new law over the financial institutions that were authorized by the government to offer the payroll loans. In this case all financial institutions of the sample became able to offer payroll credit at one point in time (the month that the institution signed the contract with INSS).

The table 4 presents the estimation results of the equation (1) for both the dependent variables: new loans ( $\mathrm{R} \$$ millions) and interest rate (\% per month). Column 1 report the direct effect of the new law on new personal loans. It is associated with an increase of $\mathrm{R} \$ 46.6$ millions in the personal credit negotiated by the financial institutions allowed to offer the payroll loans. The average of new loans for this group before the new law was $\mathrm{R} \$ 57$ millions, occurring an increase of $\mathrm{R} \$ 70$ millions after the new law. Thus, approximately $67 \%$ of such increase was caused by the new law. The column 2 that presents the direct effect over the interest rate points to a decrease of $0.62 \%$ per month, which means a decrease of $7.4 \%$ per year. Comparing to the levels of interest rate for the this group before treatment period we can say that the new law brought a reduction of approximately $11 \%$ in the rate ( $44 \%$ of the post-treatment total fall). Both estimations are statistically significant at $1 \%$ level.

Both effects are according to our expectations. Since the new law reduces the moral hazard problem, it increases the expected return of lenders due to the reduction of probability debtors' default. It induces the lenders to expand the supply credit at better terms. In response to this improvement in the personal credit, debtors tend to demand such type of loans. 
Table 4: Difference-in-Difference Models for the direct effect ${ }^{\star}$ New Loans Interest Rate ( $\mathrm{R} \$$ millions $) \quad$ (\% per month)

\begin{tabular}{lcc} 
Personal Loans $(=1)$ & $\begin{array}{c}46.6 \\
(<0.01)\end{array}$ & $-0.62 \%$ \\
& & $(<0.01)$ \\
\hline fixed effects & Yes & Yes \\
$\mathrm{R}^{2}$ & 0.91 & 0.93 \\
Number of obs & 1850 & 1627 \\
\hline
\end{tabular}

${ }^{*}$ p-value in parentheses

Robust standard errors

\subsection{Indirect Effects}

In this subsection we analize the indirect effect of the new law. This effect is defined as the impact of the new law on financial institutions that were not allowed to offer the payroll loans. Since the procedure of making financial institutions able to offer payroll loans is continuous through time ${ }^{11}$, we use as threshold point different dates to capture the new law's effect.

Tables 5 and 6 present the estimation results of the equation (1) for both dependent variables: interest rate (\% per month) and new loans ( $\$$ \$millions) respectively. Columns 1 to 4 of the table 5 report the results for interest rate varying the threshold point that defines the pre- and posttreatment period to the financial institutions that are not able to offer payroll loans. The indirect effect of the new law is associated with a decrease in the interest rate of personal loans varying from $0.41 \%$ to $0.43 \%$. Comparing to the levels of interest rate for the this group before treatment period $(5.5 \%)$ we can say that the new law produced, at most, a reduction of $7.8 \%$ in the rate (61\% of the total fall, since the post-treatment interest rate is $4.8 \%$ ). Also, the columns 1 to 4 of the table 6 show that the new law is associated with a reduction in the new personal loans, which increases - together with the number of financial institutions that provide payroll loans - from $\mathrm{R} \$ 14.1$ millions to $\mathrm{R} \$ 19$ millions. All results are highly significant.

Table 5: Difference-in-Difference Models for the indirect effect Interest Rate (\% per month)*

\begin{tabular}{lcccc}
\hline & OLS (1) & OLS (2) & OLS (3) & OLS (4) \\
\hline Personal Loans $(=1)$ & & & & \\
& $-0.41 \%$ & $-0.40 \%$ & $-0.43 \%$ & $-0.43 \%$ \\
& $(<0.01)$ & $(<0.01)$ & $(<0.01)$ & $(<0.01)$ \\
\hline fixed effects & & & & \\
Threshold Point & Yes & Yes & Yes & Yes \\
$\mathrm{R}^{2}$ & May 2004 & September 2004 January 2005 & May 2005 \\
Number of obs & 0.88 & 0.88 & 0.88 & 0.88 \\
\hline${ }^{*}$ p-value in parentheses & 3313 & 3313 & 3313 & 3313 \\
Robust standard errors & & & &
\end{tabular}

\footnotetext{
${ }^{11}$ See Table A1 at Appendix A.
} 
Table 6: Difference-in-Difference Models for the indirect effect New Loans (R\$ millions)*

\begin{tabular}{lcccc}
\hline & OLS (1) & OLS (2) & OLS (3) & OLS (4) \\
\hline Personal Loans $(=1)$ & & & & \\
& -14.1 & -15.9 & -16.1 & -19.0 \\
& $(<0.01)$ & $(<0.01)$ & $(<0.01)$ & $(<0.01)$ \\
\hline fixed effects & & & & \\
Threshold Point & Yes & Yes & Yes & Yes \\
$\mathrm{R}^{2}$ & May 2004 & September 2004 January 2005 & May 2005 \\
Number of obs & 0.90 & 0.90 & 0.90 & 0.90 \\
${ }^{*}$ p-value in parentheses & 3709 & 3709 & 3709 & 3709 \\
Robust standard errors & & & &
\end{tabular}

Notice that the indirect effect is instantaneous for both variables of personal loans. The intuition behind this result is that the volume of new loans decreases due to the migration of the clients from the financial institutions not authorized to supply payroll loans to institutions able to offer this type of credit, looking to change the more expensive credit to the cheaper loan. Since this movement represents a contraction in the demand for personal loans in such financial institutions, the equilibrium interest rate tends to reduce, as the empirical results indicates.

\subsection{Equilibrium Effects}

The table 7 presents the estimation results of the equation (1) for the dependent variable interest rate (\% per month). Columns 1 to 4 report the results varying the threshold point that defines the pre- and post-treatment period to the financial institutions that are not able to offer payroll loans. The effect of the new law is instantaneous on interest rate. In equilibrium, the new law is associated with a decrease in the interest rate of personal loans varying from $0.34 \%$ (threshold in May 2004) to $0.52 \%$ (threshold in May 2005), with all cases being statistically significant at $1 \%$. Comparing to the levels of interest rate for the treatment group before treatment period we can say that the new law produced, at most, a reduction of $10.3 \%$ in the rate $(58 \%$ of the total fall).

Table 8 presents the diff-in-diff coefficient results for new personal loans variable ( $\mathrm{R} \$$ millions). Columns 1 to 3 report the results for new loans as dependent variable varying the threshold point that defines the pre- and post-treatment period to the financial institutions that are not able to offer payroll loans. We find that, in equilibrium, the new law is associated with an increase in the new personal loans from January 2005 on, which grow through the time from R $\$ 5.9$ millions to $\mathrm{R} \$ 13.8$ millions. As we showed previously, the average of new loans for the treatment group before the new law was $\mathrm{R} \$ 35.4$ millions, occurring an increase of $\mathrm{R} \$ 33.3$ millions after the new law. Thus, the new law is responsible for approximately an increase of $42 \%$ in the new loans.

Differently from the interest rate, we notice that in this case the impact of the new law has a delay. We can explain this feature coming from three different sources: first, the initial debtors' behavior could be the migration between the both groups of financial institutions, increasing the demand for payroll loans from institutions able to supply it to repay more expensive personal loans to institutions not authorized to offer that credit, which in the aggregated level the personal loans does not suffers any change in quantity; second, the number of financial institutions that are allowed to offer payroll loans increases through the time ${ }^{12}$ and the time to spread the information about this new tecnology of loans may be slow.

\footnotetext{
${ }^{12}$ See Table A at the Appendix A.
} 
However, the final effect is according to the expectations. Such law helps to complete the contingent markets once it brings the possibility of people making contracts of future payments conditioned to future cash flow. It reduces the number of states of nature in which financial institutions would lost their money due to moral hazard actions, stimulating the supply of credit. All this factors make the volume of new loans increase. Since the new law vanishes a significant part of the default, the financial institutions will be repaid in more states of nature, increasing their expected value to be recovered. Thus, since the creditors will be repaid in a bigger share of states of nature, the cost of credit falls. These results show the potential improvements in social welfare that this law may produce.

Table 7: Difference-in-Difference Models of Interest Rate (\% per month)*

\begin{tabular}{lcccc}
\hline & OLS (1) & OLS (2) & OLS (3) & OLS (4) \\
\hline Personal Loans $(=1)$ & $-0.34 \%$ & $-0.36 \%$ & $-0.42 \%$ & $-0.52 \%$ \\
& $(<0.01)$ & $(<0.01)$ & $(<0.01)$ & $(<0.01)$ \\
& & & & \\
\hline fixed effects & Yes & Yes & Yes & Yes \\
Threshold Point & May 2004 & September 2004 January 2005 & May 2005 \\
$R^{2}$ & 0.90 & 0.90 & 0.90 & 0.90 \\
Number of obs & 4940 & 4940 & 4940 & 4940 \\
\hline
\end{tabular}

${ }^{*} p$-value in parentheses

Robust standard errors

Table 8: Difference-in-Difference Models of New Loans (R\$ millions)*

\begin{tabular}{lccc}
\hline & OLS (1) & OLS (2) & OLS (3) \\
\hline Personal Loans $(=1)$ & 5.9 & 8.2 & 13.8 \\
& $(<0.05)$ & $(<0.05)$ & $(<0.01)$ \\
\hline fixed effects & & & \\
Threshold Point & Yes & Yes & Yes \\
$\mathrm{R}^{2}$ & 0.90 & March 2005 & May 2005 \\
Number of obs & 5559 & 0.90 & 0.90 \\
\hline
\end{tabular}

${ }^{*} \mathrm{p}$-value in parentheses

Robust standard errors

Using the difference-in-difference methodology we are able to take out the bias of a "pure estimator". We showed in later section that the new loans' volume increased for both treatment and control group between pre- and post-treatment periods. So it is important to control for this generalized trend of growth in the credit market through the use of this estimator. The results show that even controlling for common temporal trends and for cross-section heterogeneity (the time and cross section fixed effects) the new law's effect on new loans is economically and statistically significant. It means the new loans' growth between pre- and post-treatment periods was much bigger for treatment group than for control group even when we control for these factors.

The economic improvement that the new law brought by eliminating part of the moral hazard was not only statistical but also economic significant. Thus, this findings allow us to notice how costly is informational failures.

\subsection{The estimated elasticity of the supply curve of personal loans}

We showed in the previous sections the estimated impact of the new law in the personal credit market. We called of indirect effect the estimated impact on institutions not able to give payroll 
loans according to the new law. For these institutions the payroll loans meant a pure demand shock (as we saw in the indirect effects subsection), which provide to us the opportunity to measure the credit supply elasticity for personal loans using the estimated effect of the new law.

\section{Figure 6: Supply and Demand curves of personal loans}

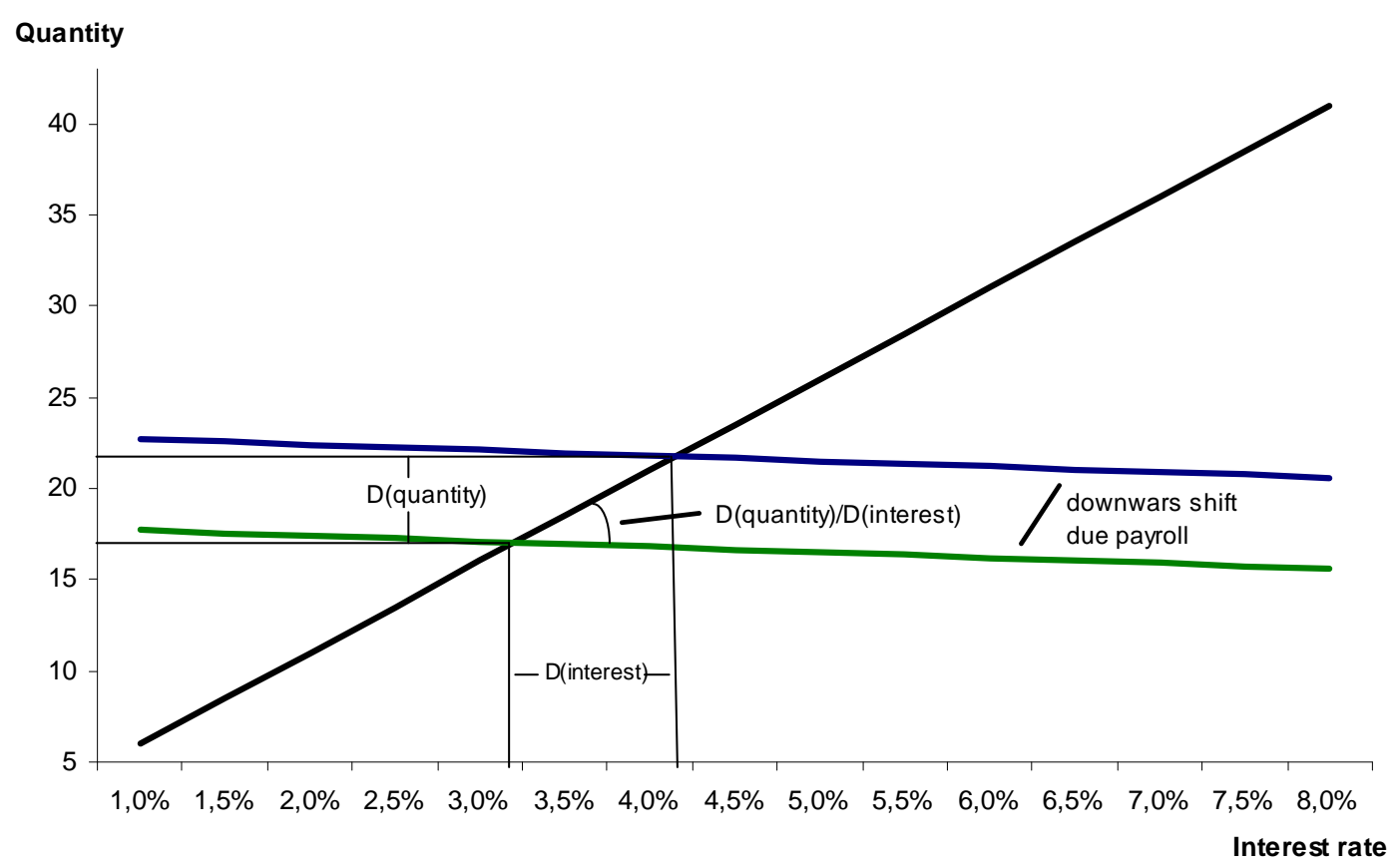

The $D$ (quantity) (or $\Delta$ quantity) is the payroll loans effect for new loans volume while $D$ (interest) is the interest rate effect of the new law. From these measures we can calculate the interest rate derivative of the credit supply, $D$ (quantity) $/ D$ (interest). In order to get the elasticity we have to multiply this derivative by interest/quantity in the point where the derivative is calculated. This point is exactly the period before the new law takes effect, so we get the interest rate average before new law takes effect divided by new loans average in the same period. It's important to note that this is a measure of an "average" elasticity, since we are using average effects and average values of the variables levels. Besides that, the measure is approximated, once the interest rate variation is not necessarily infinitesimal. Even so this is an important attempt to get a number for credit supply elasticity from empirical estimation.

The table below shows the estimates of credit supply elasticity for personal loans. Each of them uses a cut date for the beginning of the treatment. The estimates vary from 8.7 to 10.8 which mean that a $1 \%$ increase in the interest rate implies a decrease in the new loans volume from $8.7 \%$ to $10.8 \%$. This is a high value for elasticity; this mean that if there is a demand shock decreasing interest rate from $5 \%$ per month to $4.75 \%$ per month, new loans volume would fall, on average, between $43.5 \%$ and $54 \%$.

This elasticity measure has important implications concerning monetary policy transmission. If there is a credit channel of monetary policy, this measure would say to us how credit supply for household would respond when facing variations of credit demand caused, for example, by a monetary policy restrictive. This number is also important for calibrating theoretical models with a banking sector for the Brazilian economy. 


\begin{tabular}{lc}
\multicolumn{2}{c}{ Elasticities } \\
\hline Threshold date & $\% \mathrm{D}$ (quantity) $/ \% \mathrm{D}$ (interest rate) \\
December of 2004 & 9,7 \\
January of 2005 & 8,8 \\
February of 2005 & 8,7 \\
March of 2005 & 9,0 \\
April of 2005 & 8,7 \\
May of 2005 & 9,7 \\
June of 2005 & 9,7 \\
July of 2005 & 10,8
\end{tabular}

\section{Conclusion}

The new Brazilian law of payroll loans, launched in September 2003, provides a natural experiment on personal credit, since it was an exogenous change that affected only a specific type of loans: the payroll loans. The payroll loan is a type of personal credit with repayments directly deducted from the borrowers' payroll check, which, in practice, makes a collateral out of future income.

The new law provides to creditors the capacity to receive their loans' repayment immediately, whenever the debtors have enough income to do it. Thus, such type of loan eliminates a significant part of the strategic default, diminishing the informational failure costs, as moral hazard. Theoretically, financial institutions will be more willing to offer better terms of credit since the expected value of the loan's repayment increases due to the lower probability of default.

The empirical methodology applied to identify the average effect of the new law on personal credit - more specifically over the amount of new loans and interest rates - was the difference-indifference procedure. The results point to an increase in the new loans and to a fall in the interest rate. In quantitative terms, our estimation indicates an increase of approximately $42 \%$ in the new loans and a decrease of $10.3 \%$ in the interest rate. Therefore, the main result of this paper shows that the information failures produces a significant economic cost in the personal credit market.

Besides the final impact over personal loans, we estimate both the direct and indirect effects of the new law. For the first we find that the new law caused an increase of $\mathrm{R} \$ 46$ millions in new personal loans for institutions that are able to offer the payroll loans, while the indirect effect suffered a contrary effect. Mainly due to the migration for the less expensive credit as the payroll loans, the non authorized institutions had their loans reduced in $\mathrm{R} \$ 19$ millions. The interest rate falls for both groups but for different reasons, for the first group the lower probability of default provide a higher expectations about recovery of the debt, which induces creditors to offer the credit at better terms, while for the second group a reduction in the demand forces the interest rate down.

This reduction of the demand for the group of institutions not authorized to offer payroll loans allowed us to estimate the credit supply elasticity of personal loans. The results point to an estimated elasticity varying from 8.7 to 10.8 , which means that a $1 \%$ variation in the interest rate causes new loans variation between $8.7 \%$ and $10.8 \%$. Thus, the estimated elasticity shows a very steep supply curve of personal credit.

\section{References}

[1] Arida, Persio, Bacha, Edmar L., Lara-Resende, André "Credit, Interest, and Jurisdictional Uncertainty: Conjectures on the Case of Brazil", Inflation Targeting, Debt and the Brazilian Experience, The MIT Press, 2005. 
[2] Banerjee, Abhijit V., Gertler, Paul J. and Ghatak, Maitreesh "Empowerment and efficiency: tenancy reform in West Bengal", Journal of Political Economy, 2002, vol.110, no.2, pp. 239-80.

[3] Baltensperger, E. "Credit rationing: issues and questions". Journal of Money, Credit and Banking, 1978, 10(2): 170-83.

[4] Freixas, Xavier; Rochet, Jean-Charles, "Microeconomics of banking", Cambridge, Massachusetts: The MIT Press.

[5] Castelar, Armando "Judiciário, reforma e economia: A visão dos magistrados." Working paper 966. Rio de Janeiro: Institute of Applied Economics Research, 2003.

[6] Coelho, Christiano A., Garcia, Marcio and Mello, João M. "Testing for credit rationing in Brazilian market", Mimiographed, PUC-Rio, 2006.

[7] Costa, Ana C. and Mello, João M. "Judicial Risk and Creditor Expropriation: Micro Evidence from Brazilian Payroll Loans", PUC-Rio Workshop, 2005.

[8] Meyer, Bruce D. "Natural and quasi-experiments in economics", Journal of Business and Economics Statistics, 13 (2): 151-161, 1995.

[9] Stiglitz, Joseph E., Weiss, Andrew, "Credit rationing in markets with imperfect information", American Economic Review, vol. 71, no.3, 1981.

[10] Wooldrige, J. M., "Econometric analysis of cross section and panel data", Cambridge, Massachusetts: The MIT Press.

\section{A Appendix}

\begin{tabular}{|lc|}
\hline \multicolumn{2}{|c|}{ Table A1 - Number of institutions signing the deal with INSS by month } \\
\hline May of 2004 & 1 \\
September of 2004 & 1 \\
November of 2004 & 4 \\
December of 2004 & 6 \\
January of 2005 & 3 \\
March of 2005 & 2 \\
April of 2005 & 5 \\
May of 2005 & 5 \\
June of 2005 & 5 \\
August of 2005 & 8 \\
\hline
\end{tabular}

Source: Homepage of national press (diário oficial): $h$ ttp://www.in.gov.br/imprensa/in 